\title{
Phenotypic Identification of Lactic Acid Bacteria Isolated from Tempoyak (Fermented Durian) Made in the Philippines
}

\author{
Neti Yuliana (Corresponding author) \\ Department of Agro industrial Technology (THP), Faculty of Agriculture, \\ University of Lampung, Sumantri Brojonegoro\#1, Bandar Lampung, Indonesia \\ Tel: 62-0721-781-498_E-mail: yuliana_thp@unila.ac.id \\ Erlinda I. Dizon \\ Institute of Food Science and Technology, College of Agriculture \\ University of the Philippines Los Baños, College, Laguna, Philippines - 4031 \\ Tel: 63-049-536-2312 E-mail: ei_dizon@yahoo.com
}

Received: January 26, 2011 Accepted: February 09, 2011 doi:10.5539/ijb.v3n2p145

The research is financed by the Southeast Asian Regional Center for Graduate Study and Research in Agriculture (SEARCA), University of the Philippines Los Baños, College, Laguna - 4031

\begin{abstract}
Nine (9) Gram-positive bacteria, isolated from 8-day old fermenting durian (tempoyak) made in the Philippines were classified and subjected to phenotypic analyses. Based on morphological and biochemical characteristics, the lactic acid bacteria (LAB) isolates were identified as Lactobacillus plantarum, Lactobacillus sp, Weissella paramesenteroides and Pediococcus acidilactici. This is the first report for the presence of Weissella sp and Pediococcus sp in tempoyak. Live cells of LABs in tempoyak makes it a functional food and probably with potential as probiotic product.
\end{abstract}

Keywords: Lactic acid bacteria, Tempoyak, Phenotypic analysis, Lactobacillus, Weissella, Pediococcus

\section{Introduction}

Tempoyak is the fermented pulp of durian fruit that has distinctive durian smell and a creamy yellow color and is widely consumed in both Malaysia and Indonesia as side dish and condiment (Battcock and Ali, 1998; Irwandi and Che-Man, 1996; Gandjar, 2000). As a condiment, tempoyak is used with certain fish and vegetables dishes. This condiment is made by mixing durian pulp with salt and fermented under partially anaerobic condition at ambient temperature in a closed container. Fermentation usually takes about 4-7 days and the texture of durian pulp changes from a solid to a semisolid consistency with acid odor and dominant taste. The acidity of tempoyak was reported as approx. 2.8 to 3.6\% (Amin et al., 2004, Leisner et al., 2002).

The sour taste of tempoyak is attributed to the acid produced by lactic acid bacteria (LAB) during fermentation. Earlier studies showed that LAB were the predominant microorganism in tempoyak (Leisner et al., 2001; Amiza et al., 2006). The chemical composition of the durian fruit, with 15-20\% total sugar (Ketsa and Daengkanit, 1998) is expected to support the growth of lactic acid bacteria. Species of Lactobacillus have been reported as the main LAB isolated from tempoyak made in Indonesia and Malaysia. It is expected that strains of LAB and other microorganisms vary depending on the place where the product is prepared. Lb. plantarum, Lb. brevis, Lb. mali, Lb. fermentum were found in tempoyak from Malaysia (Issa 2000, Leisner et al., 2001), while Wirawati (2002) and Ekowati (1998) isolated Lb. plantarum, Lb. casei, Lb. corynebacterium and Lb. fersantum, Lb. casei, respectively, from tempoyak in Indonesia. Leisner et al., (2002) reported the new species of Lactobacillus, L. durianis sp., isolated from Malaysian tempoyak. Other LAB present in tempoyak from Malaysia was Leuconostoc mesenteroides (Leisner et al., 2001).

In general, LABs are the most important microorganisms in fermented fruits and vegetables. There are several potential health and nutritional benefits from LAB which are sometimes known as "probiotics". Bacteria that 
lives in the human intestine and control the balance of intestinal microflora finally elicit physiological and beneficial effects on health of the host have been recently been named as "probiotics" (Saito, 2004). In 2002, Tannock defined probiotics as "living microorganisms, which upon ingestion in certain number, exert health benefits beyond inherent basic nutrition'. Probiotics have been suggested to have the following properties and functions: adherence to host epithelial tissues; acid resistance and bile tolerance; elimination of pathogens or reduction in pathogen adherence; production of acids, hydrogen peroxide and bacteriocin antagonistic to pathogen growth; safety, non-pathogenic and non-carcinogenic; and improvement of intestinal microflora.

Unlike other neighboring countries, Filipinos are just beginning to appreciate the taste of durian fruit due to its strong, strange flavor. Durian can be eaten as fresh, used as flavoring agent for ice cream, and processed into candies and other delicacies. Lactic acid fermented durian is not known in the Philippines. However, with the consumers' clamoring for natural and healthy foods nowadays, isolation of useful microorganisms from traditional fermented products becomes the target of several investigations. Thus, this study aimed to identify the predominant lactic acid bacteria present in tempoyak made in the Philippines based on the LAB phenotypic characteristics.

\section{Materials and Methods}

Fully ripened durian (Durio zibethinus Murr.) fruits were obtained from local grower of durian in Los Baños, Laguna, Philippines. Microbiological media were purchased from Merk Company and all other chemicals were of analytical grade.

\subsection{Fermented Durian Preparation}

Prior to this study, the author observed actual commercial processing of tempoyak in Indonesia. In the laboratory, different salt concentrations were tested in the preparation of tempoyak to identify the optimum formulation. The optimum salt concentration was selected in the succeeding experiment. Tempoyak was prepared in triplicates by mixing durian pulp with salt ( $3 \%$ by weight). The mixtures were placed in sealed plastic containers and allowed to naturally ferment for 8 days at ordinary room temperature $\left(28\right.$ to $\left.34^{\circ} \mathrm{C}\right)$.

\subsection{Isolation and Purification of $L A B$}

Samples of an 8-day old fermented durian (tempoyak) were analyzed microbiologically for the presence of LAB. The standard pour plating technique was used for the enumeration of acid producing bacteria. Briefly, a 25 -gram sample was added with $225 \mathrm{ml}$ of $0.1 \%$ sterile peptone water (as diluents), homogenized and series of dilutions were performed. An aliquot $(1 \mathrm{ml})$ of the appropriate dilutions were plated out (duplicates) using Glucose Yeast Peptone (GYP) agar medium plus calcium carbonate (1.0\%). The plates were incubated upside down at $30 \mathrm{C}$ for $48 \mathrm{hrs}$. Acid formers were identified by the presence of a zone of clearing the $\mathrm{CaCO}_{3}$ around the colonies. Plates containing separated colonies were selected for isolation. The colonies of acid forming microorganisms were transferred by stabbing into tubes of GYP agar. Purification of the isolates was done by repeated pour plating technique using the same agar medium until pure cultures were obtained. Pure cultures were transferred and maintained in de Man Rogosa and Sharpe (MRS) agar stabs. Duplicate tubes of the isolates were prepared, one tube was stored in refrigerator as stock culture, and the other tube was used for identification studies.

\subsection{Identification of LAB Isolates}

Cultural, morphological, physiological and biochemical tests were done following the method developed by Kozaki, et al (1992) to identify the LAB isolates. Morphological characteristics, i.e. shape, form and cell arrangement, were elucidated by scanning electron microscopy (SEM). In addition, motility test, spore formation, and Gram reaction (Harrigan, 1998) were performed as taxonomic indices. Oxygen requirement, catalase test and cultural growth on GYP soft agar stab were conducted. The ability to ferment different type of carbohydrates was performed using API $50 \mathrm{CH}$ test kit. On the other hand, gas production of the isolates was used as an index of type of fermentation grown in broth culture with inverted Durham tubes. Motility was observed on soft agar medium. Genotypic characteristic of selected isolate was elucidated by 16S rRNA sequencing analysis at Nodai Culture Collection Center, Tokyo University of Agriculture, Tokyo, Japan. Sequence alignment was conducted using the BLAST software from the Gen Bank.

\section{Results}

Out of 30 isolates, 9 acid forming bacteria were initially chosen based on their growth appearance on GYP soft agar and MRS agar media. All isolates were found non-motile and microaerophilic, where optimum growth was observed just below the surface of the media. Gram staining revealed that all isolates were Gram-positive. Spore formation was also observed and all isolates were found to be non-spore formers. Isolates were then grouped based on their form, cell arrangements, Gram reaction, catalase production, motility, spore formation, and gas 
production from glucose (Table 1), as well as the growth characteristics of isolates at different temperatures, $\mathrm{pH}$ and $\mathrm{NaCl}$ concentrations (Table 2).

Based on the shape, form and cell arrangement observed under the scanning electron microscope, the acid-forming microorganisms were then eventually grouped according to cell shape, as cocci and rods. Seven (7) of nine (9) isolates were found to be the rod-shaped strains with long and rounded ends mostly appeared as chains of 4-5 cells, pairs or single cells and these could presumptively determined as derivatives of the genus Lactobacillus. The rest of the isolates (2) were cocci, single, tetrads cell arrangement therefore they tentatively referred to Pediococcus (Figure 1a). Physiological test in relation to fermentation type for the rod-shaped strains (7) showed 5 out of 7 strains do not produce gas from glucose (Table 1).

In API CH assay, all of LAB isolates were screened for their performance regarding growth characteristics in 49 carbon sources and the results of carbohydrates fermentation are shown in Table 3. All isolates fermented L arabinose, ribose, galactose, D-glucose, D-fructose, D-manose, $\mathrm{N}$ acetyl glucosamine, amygdaline, lactose, trehalose, saccharose, trehalose and $B$ gentibiose. Only isolates of Pediococcus group could utilize D-tagatose. This physiological test was able to identify species of homofermentative Lactobacillus (2 strains) and Weissella ( 2 strains) while the three (3) remaining strains of heterofermentative Lactobacillus were not clearly identified down to species level on phenotypic tests only.

\section{Discussion}

A total of 9 acid producing bacterial strains isolated from tempoyak were considered as presumptive LAB because they were Gram positive, catalase-negative, microaerophilic, non-motile and non-spore forming. Of the 9 strains, 2 were tetrad-forming cocci classified under the genus Pediococcus. The Pediococcus isolates selected for species identification grow at $\mathrm{pH} 6.5$ and $50^{\circ} \mathrm{C}$. Following the scheme presented in LAB identification manual of Kozaki et a.l (1992), the isolates were identified as Pediococcus acidilactici, the only species of Pediococcus that can grow at $50^{\circ} \mathrm{C}$ and $\mathrm{pH}$ 6.5. This strain fermented arabinose, and tagatose but did not utilize sorbitol, melibiose, melezitose, or xylose (Table 3). From industrially -useful LAB point of view, the ability to grow at high temperature is a desirable trait as it could translate to increased rate of growth and lactic acid production. Presence of this thermophilic Pediococcus is probably caused by high temperature especially during summer months in the Philippines when the tempoyak was made for this study. This existence of thermophilic, homofermentative P. acidilactici, implies that tempoyak product has enough organic acid (lactic acid) for flavor and shelf stability against spoilage microorganisms.

The remaining isolates (7) were rods, and were subjected to the type of fermentation to determine whether the isolates are homofermentative or heterofermentative. LABs that produce substantial amount of gas $\left(\mathrm{CO}_{2}\right)$ are termed as heterofermentative (heterolactics) while those that produce only trace amount or no gas formation on glucose as carbon source are known as homofermentative (homolactics). Gas formation is indicated on the inverted Durham tubes after the desired incubation time during the test for sugar fermentation. The five isolates producing gas from glucose were identified as either heterofermentative Lactobacillus or Weissella (Table 1). The remaining two (2) isolates that were not able to produce gas from glucose were identified as homofermentative Lactobacillus. The homofermentative Lactobacillus isolates were identified based on their ability for carbohydrate fermentation following the LAB identification scheme of Kozaki et al., (1992). The 2 selected isolates were found positive for gluconate and arabinose fermentation, but negative for xylose. Hence, these isolates were tentatively identified as Lactobacillus plantarum (Figure 1d). The results of 16S rRNA sequencing analysis of the heterofermentative Lactobacillus isolate (Figure 2) further confirmed this species with 99\% similarity when compared to nucleotide data in Gene Bank using BLASTN sequence alignment from NCBI for the nucleotide comparison. Association of Lb. plantarum with tempoyak, acid-fermented durian, is not surprising. It is well known that this isolate has role in some acid-fermented vegetable foods such as sauerkraut, Korean kimchi and fermented bamboo tender shoots (Steinkraus et al.,1983; Battcock and Ali,1998; Tamang et al., 2008). Products containing live and useful microorganisms like LABs are considered "probiotics" since consumption of these foods benefited the host by improving the properties of indigenous intestinal microflora (Havenaar and Veld, 1992).

Members of the genus Weissella may be distinguished readily from homofermentative Lactobacilli, Pediococci, Enterococci, Lactococci and Streptococci by the formation of gas from carbohydrates. A cell wall murein based upon lysine with an interpeptide bridge containing alanine, or alanine plus serine or glycine distinguishes Weissella from heterofermentative Lactobacilli (Collins et al., 1993). Additional test with regards to their ability to grow at $45^{\circ} \mathrm{C}$ was also done to differentiate Lactobacillus and Weissella. Following the taxonomic studies by Collins et al., (1993), growth does not occur at $45^{\circ} \mathrm{C}$ for Weissella (with the exception of W. confusa). Based on 
this characteristic and differences of cell form, the three isolates are probably heterofermentative Lactobacillus and the two remaining isolates belong to Weissella.

The capability of strains for carbohydrate fermentation was used to identify species of heterofermentative Lactobacillus. These isolates were found positive for fructose, ribose and mannose fermentation. Based on the scheme described by Kozaki et al., (1992), these isolates were probably Lactobacillus viridans, Lb. confusus, Lb. halotolerans, Lb. minor, Lb. bifermetans or Lb. divergens. To further confirm the identity of the isolates, determination of peptidoglycan cell wall type and other test is needed.

The Weissella group was identified down to the species level through the production of acid anaerobically from glucose, L arabinose, cellobiose, galactose, maltose,melibiose, raffinose, ribose, sucrose, trehalose and xylose (Collins et al., 1993). The isolate tested were found positive for acid production from glucose, L- arabinose, cellobiose, galactose, maltose,melibiose, raffinose, ribose, sucrose, trehalose but negative for xylose, hence, the isolates were identified as Weissella paramesenteroides (Figure1c).

Overall, the prevalent LAB belonged predominantly to genera Lactobacillus, consisted of Lactobacillus $s p$ and Lactobacillus plantarum, while others were identified as Weissella paramesenteroides and Pediococcus acidilactici. A similar study on the biodiversity of lactic acid bacteria from Malaysian and Indonesian tempoyak also found that Lactobacillus strains were predominant members of LAB flora (Leisner et al., 2001; Wirawati, 2002). This is the first report on the presence of Pediococcus sp and Weissella sp isolated from tempoyak that is probably due to the differences in microflora as affected in general by variety of raw materials, ingredients, and other environmental conditions

\section{Conclusion}

On the basis of phenotypic and genotypic (for Lb. plantarum) properties, the lactic acid bacterial population in tempoyak prepared in the Philippines consisted of: Lactobacillus sp, Lactobacillus plantarum, Weissella paramesenteroides, and Pediococcus acidilactici. The majority of the acid forming bacteria belongs to the genera Lactobacillus, $40 \%$ of which were Lactobacillus plantarum while the remaining strains were still unidentified. For the unidentified strains, there is a need further examination with regards to phylogenetic determination because of the inability of biochemical tests to differentiate strains among Lactobacillus. Presence of live LABs suggests that this resulting product has a potential to be included as a probiotic food, since its consumption could possibility benefit the host by improving the properties of indigenous intestinal microflora.

\section{References}

Amin, M.A., Zakiah, J., \& Khim, Ng. L. (2004). Effect of salt on tempoyak fermentation and sensory evaluation. Journal of Biology Science, 4, 650-653.

Amiza, M.A., Zakiah, J., Khim, Ng L., \& Lay K.W. (2006). Fermentation of tempoyak using isolated tempoyak culture Research Journal of Microbiology, 1,243-254.

Battcock, M., \& Ali, S.A. (1998). Fermented fruits and vegetables, a global perspective FAO Agricultural Services Bulletin No 134, Rome, Italy.

Collins, M.D., Samelis, J., Metaxopoulus, J. \& Wallbanks, S. (1993). Taxonomic studies on some Leuconostoc-like organism from fermented sausages: description of a new genus Weissella for Leuconostoc paramesenteroides group species. Journal of Applied Bacteriology, 75,595-603.

Ekowati, C.N. (1998). Mikroflora pada fermentasi daging buah durian (tempoyak). Jurnal Sains dan Teknologi Edisi Khusus, 136-141.

Gandjar, I. (2000). Fermentations of the far east. In RK Robinson,.C.A. Batt \& P.D. Patel, (eds). Encyclopedia of Food Microbiology. New York: Academic Press. 767-773.

Harrigan, W.F. (1998). Laboratory methods in food microbiology). New York: Academic Press. pp. 34-35.

Havenaar, R. \& J.H. Veld. (1992). Probiotics, a general view: The lactic acid bacteria in health and disease. London: Elsevier Applied Science.

Irwandi \& Che-Man, Y.B. (1996). Durian leather: development, properties and storage stability. Journal of Food Quality, 19, 439-489.

Issa, Z. M. (2000). Molecular characterization of Lactobacillus plantarum isolated from Malaysian fermented foods. [MS Thesis]. Universiti Putra Malaysia.

Ketsa, S. \& Daengkanit, T. (1998). Physiological changes during postharvest ripening of durian fruit (Durio zibethinus Murray), The Journal of Horticultural Science \& Biotechnology, 73, 575-577. 
Kozaki, M., Uchimura, T., \& Sanae, O. (1992). Laboratory manual for identification of lactic acid bacteria. Tokyo. Japan: Asakura Bookshop.

Leisner, J.J., Vancanneyt, M., Rusul, G., Pot, B., Lefebvre, K., Fresi, A., \& Tee, LK. (2001). Identification of lactic acid bacteria constituting the predominating microflora in acid-fermented condiment (tempoyak) popular in Malaysia. International Journal of Food Microbiology, 63,149-157.

Leisner, J.J., Vancanneyt, M., Lefebvre, K., Vandemeulebroecke, K., Hoste, B., Vilalta, N.E., Rusul, G., \& Swings, J. (2002). Lactobacillus durianis sp.nov., isolated from an acid-fermented condiment (tempoyak) in Malaysia. International Journal of. Systematic and Evolutionary Microbiology, 52, 927-931.

Saito, T. (2004). Selection of useful probiotic lactic acid bacteria from the Lactobacillus acidophilus group and their applications to functional foods. Animal Science Journal, 75,1-13

Wirawati, C.U. (2002). Potensi bakteri asam laktat yang diisolasi dari tempoyak sebagai probiotik [MS Thesis], Bogor: Institut Pertanian Bogor, Indonesia.

Steinkraus, K.H., Cullen, R.E., Pederson, C.S., Nellis, L.F., \& Gavvitt, B.K. (1983). Handbook of indigenous fermented foods. New York: Marcel Dekker, Inc.pp.128-130.

Tamang, B., Tamang, J.P., Schillinger, U., Franz, CMAP., Gores, M., \& Holzapfel, W.H. (2008). Phenotypic and genotypic identification of lactic acid bacteria isolated from ethnic fermented bamboo tender shoots of North East India. International Journal of Food Microbiology, 121, 35-40.

Tannock, G. W. (2002). Probiotics and prebiotics: Where are we going? Norfolk, UK: Caister Acad Press. 
Table 1. Morphological and cultural characteristics of isolates

\begin{tabular}{|c|c|c|c|c|c|}
\hline \multirow[t]{2}{*}{ Genus } & \multicolumn{5}{|c|}{ Characteristics } \\
\hline & Morphology & $\begin{array}{l}\text { Gram } \\
\text { reaction }\end{array}$ & Catalase & Motility & $\begin{array}{l}\text { Gas production/ } \\
\text { Fermentation type }\end{array}$ \\
\hline $\begin{array}{c}\text { (I) } \\
\text { Lactobacillus }\end{array}$ & $\begin{array}{l}\text { Short rods, rounded edge, } \\
0.3 \mathrm{x} 0.5 \mathrm{um}, \text { no spore } \\
\text { formation }\end{array}$ & + & - & - & $\begin{array}{c}+ \\
\text { Heterofermentative }\end{array}$ \\
\hline $\begin{array}{c}\text { (II) } \\
\text { Weissella }\end{array}$ & $\begin{array}{l}\text { Short rods, rounded edge, } \\
\text { around } 0.2 \times 0.5 \text { um, no } \\
\text { spore formation }\end{array}$ & + & - & - & $\begin{array}{c}+ \\
\text { Heterofermentative }\end{array}$ \\
\hline $\begin{array}{c}\text { (III) } \\
\text { Lactobacillus }\end{array}$ & $\begin{array}{l}\text { Short rods, straight edge, } \\
0.3 \times 0.6 u m, \text { no spore } \\
\text { formation }\end{array}$ & + & - & - & Homofermentative \\
\hline $\begin{array}{c}\text { (IV) } \\
\text { Pediococcus }\end{array}$ & $\begin{array}{l}\text { Cocci, tetrads and pairs, } \\
\text { around } 0.5 \text { um diameter, } \\
\text { no spore formation }\end{array}$ & + & - & - & Homofermentative \\
\hline
\end{tabular}

Table 2. Growth characteristics of isolates at different temperature, $\mathrm{pH}$ and $\mathrm{NaCl}$ concentrations.

\begin{tabular}{|l|c|c|c|c|}
\hline Characteristics & \multicolumn{5}{|c|}{ Isolate Groups } \\
\cline { 2 - 5 } & I & II & III & IV \\
\hline Growth at $10^{\circ} \mathrm{C}$ & + & - & + & + \\
\hline Growth at $37^{\circ} \mathrm{C}$ & + & + & + & + \\
Growth at $45^{\circ} \mathrm{C}$ & + & - & \pm & + \\
Growth at $50^{\circ} \mathrm{C}$ & - & - & - & + \\
Growth at $\mathrm{pH} 4.8$ & + & + & + & + \\
Growth at $\mathrm{pH} 6.5$ & + & + & + & + \\
Growth at $\mathrm{pH} 9.6$ & + & + & + & + \\
Growth at $3 \% \mathrm{NaCl}$ & + & + & + & + \\
Growth at $6.5 \% \mathrm{NaCl}$ & + & + & + & + \\
\hline
\end{tabular}

+ good growth; \pm very weak; - no growth 
Table 3. Carbohydrate fermentation characteristics of acid-forming bacteria.

\begin{tabular}{|c|c|c|c|c|}
\hline Sugar: & $\begin{array}{c}\text { Hetero. } \\
\text { Lactobacillus } \\
\text { (Group I) }\end{array}$ & $\begin{array}{c}\text { Weissella } \\
\text { (Group II) }\end{array}$ & $\begin{array}{c}\text { Homo. } \\
\text { Lactobacillus } \\
\text { (Group III) }\end{array}$ & $\begin{array}{l}\text { Pediococcus } \\
\text { (Group IV) }\end{array}$ \\
\hline Glycerol & - & - & - & - \\
\hline Erythritol & - & - & - & - \\
\hline D-arabinose & - & - & - & - \\
\hline L-arabinose & + & + & + & + \\
\hline Ribose & + & + & + & + \\
\hline D-xylose & - & - & - & - \\
\hline L-xylose & - & - & - & - \\
\hline Adonitol & - & - & - & - \\
\hline ß-methyl-xylose & - & - & - & - \\
\hline Galactose & + & + & + & + \\
\hline D-glucose & + & + & + & + \\
\hline D-fructose & + & + & + & + \\
\hline D-mannose & + & + & + & + \\
\hline L-sorbose & - & - & - & - \\
\hline Rhamnose & - & - & - & - \\
\hline Dulcitol & - & - & - & - \\
\hline Inositol & - & - & - & - \\
\hline Mannitol & + & + & + & - \\
\hline Sorbitol & + & + & + & - \\
\hline$\alpha$ Methyl D manoside & + & + & + & - \\
\hline$\alpha$ Methyl D glucoside & + & + & + & - \\
\hline $\mathrm{N}$ acetyl glucosamine & + & + & + & + \\
\hline Amygdaline & + & + & + & + \\
\hline Arbutin & + & + & + & + \\
\hline Esculin & + & + & + & + \\
\hline Salicin & + & + & + & + \\
\hline Cellobiose & + & + & + & + \\
\hline Maltose & + & + & + & + \\
\hline Lactose & + & + & + & + \\
\hline Melibiose & + & + & + & - \\
\hline Saccharose & + & + & + & + \\
\hline Trehalose & + & + & + & + \\
\hline Inuline & + & + & + & - \\
\hline Melezitose & + & + & + & - \\
\hline D raffinose & + & + & + & - \\
\hline Amidon & - & - & - & - \\
\hline Glycogene & - & - & - & - \\
\hline Xylitol & - & - & - & - \\
\hline B gentibiose & + & + & + & + \\
\hline D turanose & + & + & + & - \\
\hline D lyxose & - & - & - & - \\
\hline D tagatose & - & - & - & + \\
\hline D fucose & - & - & - & - \\
\hline L fucose & - & - & - & - \\
\hline D arabitol & - & + & - & - \\
\hline L arabitol & - & - & + & - \\
\hline Gluconate & - & - & + & - \\
\hline 2 Cetogluconate & - & - & - & - \\
\hline 5 Cetogluconate & - & - & - & - \\
\hline
\end{tabular}



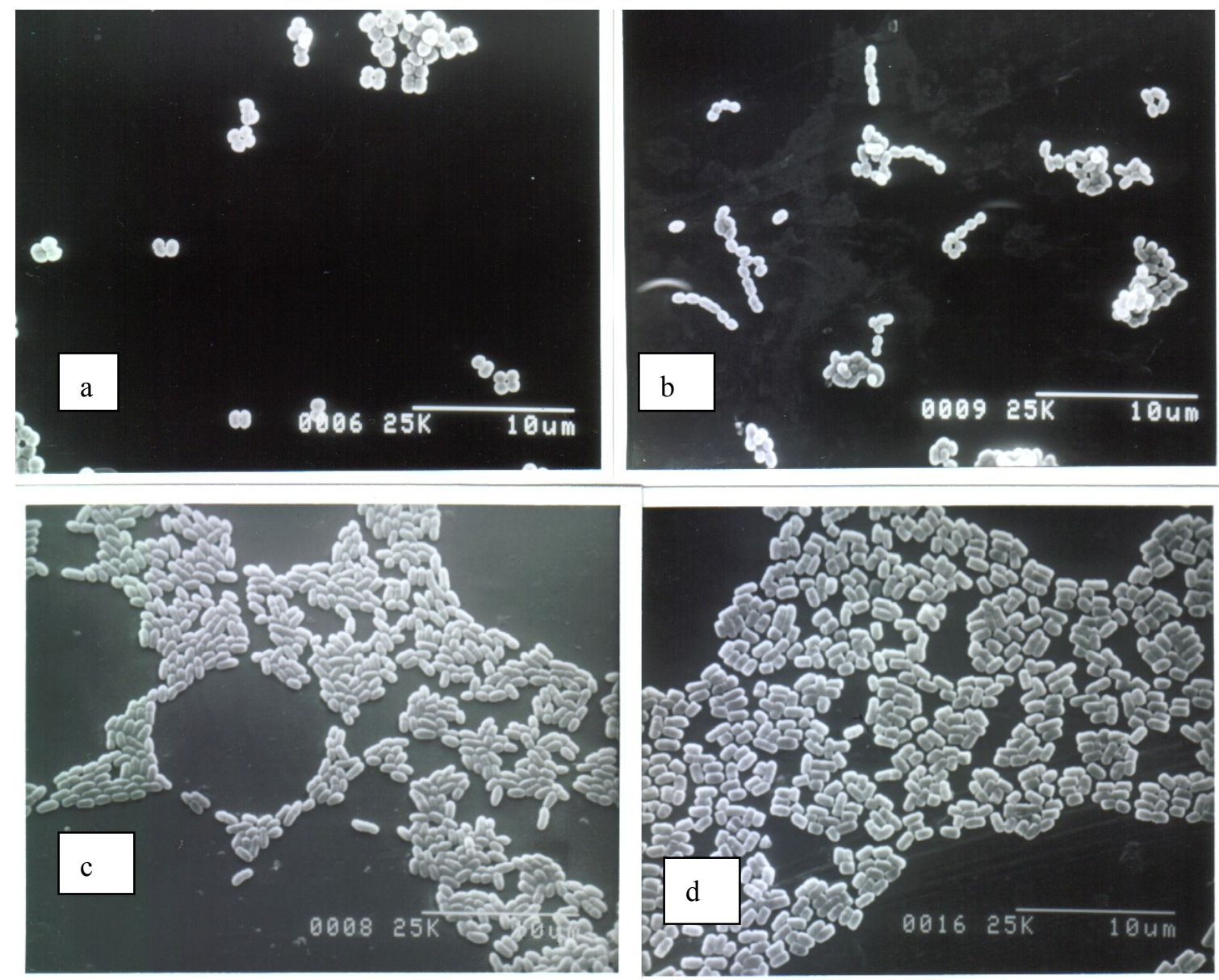

Figure 1. Identified Lactic Acid Bacteria Isolated from Tempoyak: (a) Pediococcus acidilactici,

(b) Lactobacillus sp., (c) Weissella paramesenteroides, and (d) Lactobacillus plantarum

CAAGNCGAACGAACTCTGGTATTGATTGGTGCTTGCATCATGATTTACATTTGAGTGAGTGGCGAACT GGTGAGTAACACGTGGGAAACCTGCCCAGAAGCGGGGGATAACACCTGGAAACAGATGCTAATACC GCATAACAACTTGGACCGCATGGTCCGAGTTTGAAAGATGGCTTCGGCTATCACTTTTGGATGGTCC CGCGGCGTATTAGCTAGATGGTGGGGTAACGGCTCACCATGGCAATGATACGTAGCCGACCTGAGAG GGTAATCGGCCACATTGGGACTGAGACACGGCCCAAACTCCTACGGGAGGCAGCAGTAGGGAATCT TCCACAATGGACGAAAGTCTGATGGAGCAACGCCGCGTGAGTGAAgAAGGGTTTCGGCTCGTAAAA CTCTGTTGTTAAGAAAACATATCTGAGAGTACTGTTCAGGTATTGA

Figure 2. 16S rRNA, gene sequence of Lactobacillus plantarum 